Jurnal Pendidikan dan Pembelajaran Dasar

p ISSN: $\underline{1979-5599}$ | e ISSN: 2502-194X | Sinta 3

Page | 1

\title{
PENGEMBANGAN VIDEO PEMBELAJARAN BERBASIS APLIKASI VIDEOSCRIBE PADA MATA PELAJARAN IPS DI SEKOLAH DASAR
}

\author{
Muhammad Riyanto ${ }^{1}$, Ujang Jamaludin², Aan Subhan Pamungkas ${ }^{3}$ \\ Universitas Sultan Ageng Tirtayasa Banten, Indonesia \\ 1riyanto.m27@gmail.com, 2ujangjamaludin@untirta.ac.id, 3asubhanp@untirta.ac.id
}

\begin{abstract}
DOI: $10.18860 /$ madrasah.v11i2.6419
Abstrak. Penelitian ini bertujuan untuk mengembangkan video pembelajaran berbasis aplikasi videoscribe pada mata pelajaran IPS dengan materi gejala alam. Metode penelitian yang digunakan adalah metode penelitian dan pengembangan dengan tahapan: potensi dan masalah, pengumpulan data, desain produk, validasi desain, revisi desain, dan ujicoba produk (ujicoba terbatas). Untuk menguji kelayakan dari video pembelajaran ini maka dilakukan uji validasi ahli yang dilakukan oleh ahli materi, ahli media, dan ahli pendidikan. Setelah dilakukan uji validasi oleh tim ahli, selanjutnya dilakukan ujicoba produk (ujicoba terbatas) dengan subjek penelitian yaitu 43 peserta didik kelas VI A SDN Panancangan 2. Hasil uji ahli materi menunjukkan bahwa video pembelajaran ini memperoleh nilai rata-rata sebesar 82,85\% dengan kategori sangat layak. Hasil uji ahli media video pembelajaran ini memperoleh nilai rata-rata sebesar $88,34 \%$ dengan kategori sangat layak. Hasil uji ahli pendidikan menunjukkan video pembelajaran ini memperoleh nilai rata-rata sebesar $85,83 \%$ dengan kategori sangat layak. Hasil uji coba produk (ujicoba terbatas) memperoleh nilai rata-rata sebesar 90,52\% dengan kategori sangat baik. Berdasarkan hasil penelitian dapat disimpulkan bahwa video pembelajaran berbasis aplikasi videoscibe yang dikembangkan pada peserta didik kelas VI SD sangat layak untuk digunakan dalam pembelajaran Ilmu Pengetahuan Sosial (IPS) pada materi gejala alam yang terjadi di Indonesia.
\end{abstract}

Kata Kunci. Video Pembelajaran; Videoscribe; Ilmu Pengetahuan Sosial

Abstract. This study aims to develop learning video based videoscribe applications on Social Science with the topic of natural phenomena. The research method used is research and development method with stages: potential and problems, data collection, product design, design validation, design revision, and product testing (limited trial). To test the feasibility of this video learning then tested the validation of experts conducted by material experts, media experts, and pedagogical experts. After the validation test by the expert team, then the product test (limited trial) with the subject of the research is the 43 students of class VI A SDN Panancangan 2. The results of the material expert test show that this video learning obtained an average score of $82.85 \%$ with the a very feasible category. The result of the media expert test shows that this video learning obtained an average score of $88.34 \%$ with a very feasible category. The results of the pedagogical expert test show this video learning obtained an average score of $85.83 \%$ with a very feasible category. The product trial results (limited trial) obtained an average grade of $90.52 \%$ with a very good category. Based on the results of this study, it can be concluded that learning video based on the application of videoscibe very feasible for use in Social Science on the topic of natural phenomenon in Indonesia.

Keywords. Learning Video, Videoscribe, Social Science

Received :07 February 2019 Approved :16 May 2019

\begin{tabular}{l|l} 
Revised : 13 May 2019 & Published : 30 June 2019 \\
\hline
\end{tabular}

Copyright (c) Madrasah Jurnal Pendidikan dan Pembelajaran Dasar. All Right Reserved.

This is an open-access article under the CC BY-NC-ND license

(http://creativecommons.org/licenses/by-nc-nd/4.0/).

Correspondence Address: asubhanp@untirta.ac.id

Vol. 11 No. 2 Juni 2019

Madrasah homepage: http://ejournal.uin-malang.ac.id/index.php/madrasah/index 


\section{A. PENDAHULUAN}

Pada abad ke-21 ini, telah masuk pada era globalisasi yang diikuti dengan perkembangan ilmu pengetahuan dan teknologi (IPTEK) yang begitu cepat terutama dalam bidang komunikasi dan informasi. Perkembangan ilmu pengetahuan dan teknologi tersebut menjadikan momentum untuk meningkatkan kualitas pada sumber daya manusia (SDM), termasuk SDM Indonesia. Menurut Uno dan Lamatenggo (2012:21) dalam kehidupan kita di masa mendatang, sektor teknologi informasi dan telekomunikasi merupakan sektor yang paling dominan. Siapa saja yang menguasai teknologi, maka dia akan menjadi pemimpin dalam dunianya. Oleh karena itu pendidikan haruslah mengikuti perkembangan IPTEK, karena pendidikan tidak hanya berfungsi untuk mengembangkan pengetahuan dan keterampilan serta membentuk kepribadian peserta didik untuk hidup di masa sekarang saja, tetapi untuk hidup dimasa yang akan datang. Upaya peningkatan kualitas sumber daya manusia ini, perlu didukung oleh berbagai aspek kehidupan, salah satunya adalah pada aspek pendidikan.

Pembangunan pendidikan yang sudah dilakukan di Indonesia telah memberikan hasil yang cukup mengagumkan sehingga secara umum kualitas sumber daya manusia Indonesia jauh lebih baik. Namun dibandingkan dengan negara-negara tetangga, Indonesia masih tertinggal jauh. Hal ini terjadi karena pendidikan di Indonesia belum dapat berfungsi secara maksimal. Salah satunya disebabkan karena perhatian pemerintah terhadap kualitas pendidikan masih terasa sangat minim. Gambaran ini tercermin dari beragamnya masalah pendidikan yang makin rumit seperti kualitas peserta didik masih rendah, pengajar kurang profesional, biaya pendidikan yang mahal. Rendahnya kualitas pendidikan terutama pada jenjang sekolah dasar sangat berpengaruh terhadap pendidikan selanjutnya.

Proses pembelajaran yang kurang menarik menjadikan salah satu faktor rendahnya kualitas pendidikan. Guru sebagai pengajar dan pendidik harus merancang sebuah pembelajaran yang menarik. Apabila pembelajaran yang kurang menarik dapat menimbulkan kemauan belajar pada peserta didik yang rendah, yang sering ditunjukkan dengan peserta didik masuk kelas dengan terlambat, sering melamun, kurang memperhatikan apa yang disampaikan oleh guru bahkan peserta didik cenderung memilih mengobrol dengan teman sebangkunya daripada mendengarkan apa yang dijelaskan oleh guru, seringnya ijin ke luar kelas dan ada juga yang mengganggu teman-temannya saat pembelajaran sedang berlangsung.

Tidak hanya guru yang diperlukan saat proses pembelajaran namun juga diperlukan penggunaan media pembelajaran dalam menunjang proses pembelajaran dan juga membantu guru dalam menyampaikan materi pelajaran di kelas pada proses pembelajaran. Seperti yang dikemukakan oleh Asosiasi Teknologi dan Komunikasi Pendidikan (Association of Education and Communication Technology) di Amerika (Sadiman dkk, 2010:6), media adalah segala bentuk dan saluran yang digunakan untuk menyalurkan pesan atau informasi. Media pembelajaran diperlukan dalam proses pembelajaran karena media pembelajaran mampu memberikan proses pembelajaran yang variatif sehingga dapat memudahkan peserta didik memahami materi pelajaran yang disampaikan oleh guru. Setiap pembelajaran di sekolah harus dikemas dan dirancang dengan baik, begitupula salah satunya pada pembelajaran Ilmu Pengetahuan Sosial (IPS).

Dari beragam media pembelajaran yang bisa diaplikasikan dalam pembelajaran IPS, media pembelajaran berbasis videoscribe bisa menjadi salah satu alternatif yang bisa digunakan untuk pembelajaran IPS di SD. Videoscribe sendiri merupakan media pembelajaran dengan desain whiteboard animation, yang dapat ditambahkan simbol seperti kata-kata, kalimat disertai gambar dan audiovisual, sehingga dapat membantu peserta didik memahami apa yang hendak dipesankan oleh guru yaitu berupa materi pembelajaran (Daryanto, 2010:88).

Berdasarkan hasil observasi pembelajaran IPS pada kelas VI SDN Panancangan 2, Kecamatan Cipocok Jaya, Kota Serang, ditemukan bahwa penggunaan media pembelajaran khususnya dalam pembelajaran IPS masih kurang dimaksimalkan. Adanya fasilitas LCD proyektor masih kurang dimanfaatkan oleh guru dengan baik, hal itu dapat diketahui karena guru jarang menggunakan LCD proyektor tersebut, adapun ketika guru menggunakan LCD 


\section{MADRASAH}

Jurnal Pendidikan dan Pembelajaran Dasar

p ISSN: 1979-5599 | e ISSN: 2502-194X | Sinta 3

Pa g e | 3

proyektor, cara memanfaatkannya hanya sekedar dalam menampilkan gambar dan powerpoint. Kurangnya penggunaan media pembelajaran yang lebih variatif tersebut menjadi penyebab peserta didik menjadi pasif, dan kurang interaktif dalam proses pembelajaran IPS.

Mengingat pentingnya penggunaan media pembelajaran dan besarnya manfaat yang bisa didapatkan dengan menggunakan pembelajaran, peneliti akan mengembangkan video pembelejaran pada mata pelajaran IPS materi gejala alam. Integrasi video interaktif dalam sistem pembelajaran e-learning merupakan hal yang sangat penting, hal ini sesuai dengan pendapat Zhang, D., Zhou, L., Briggs, R. O., \& Nunamaker Jr, J. F. (2006).

Selain itu menurut Annetta, L. A., Minogue, J., Holmes, S. Y., \& Cheng, M. T. (2009) menyatakan bahwa hadirnya inovasi dan teknologi (video pembelajaran) dalam pembelajaran dapat membuat siswa tertarik, dan pada akhirnya dengan ketertarikan tersebut akan memotivasi siswa sehingga siswa akan terbiasa dengan lingkungan pembelajaran tersebut.

Pengembangan video pembelajaran saat ini sangat mudah, karena tersedia banyak aplikasi yang mendukung. Salah satunya adalah aplikasi videoscribe. Videoscribe mempunya keunggulan diantaranya lebih dinamis. Berdasarkan hasil penelitian yang pernah dilakukan oleh Purnama, Erlidawati, dan Nazar (2017) mengenai media pembelajaran videoscribe, dapat diketahui bahwa aspek penyajian materi, aspek ilustrasi media, serta aspek manfaat media menjadi salah satu kriteria untuk mengembangkan video pembelajaran berbasis aplikasi videoscribe yang dapat memberikan stimulus dan keterlibatan kepada peserta didik dalam proses pembelajaran.

Maka dari itu media pembelajaran berbasis aplikasi videoscribe yang peneliti kembangkan, akan memuat materi pembelajaran gejala alam yang memudahkan peserta didik dalam memahaminya. Disertai penambahan gambar, simbol, atau ilustrasi mengenai gejala alam, serta penggunaan bentuk huruf yang lebih variatif. Sehingga diharapkan perhatian peserta didik akan lebih terpusat dan meningkatkan keaktifan mereka dalam proses pembelajaran.

\section{B. METODE PENELITIAN}

Metode penelitian yang digunakan adalah metode penelitian dan pengembangan atau Research and Development (R\&D) yaitu metode penelitian yang digunakan untuk menghasilkan produk tertentu dan menguji keefektifan produk tersebut (Sugiyono, 2015:407). Penelitian R\&D ini menghasilkan produk berupa video pembelajaran berbasis aplikasi videoscribe.

Desain penelitian yang digunakan mengacu pada langkah-langkah penelitian dan pengembangan yang telah dikembangkan oleh Sugiyono (2015:409) yaitu potensi dan masalah, pengumpulan data, desain produk, validasi desain, revisi desain, dan ujicoba produk (ujicoba terbatas).

Gambar B.1 Langkah-langkah Desain Penelitian

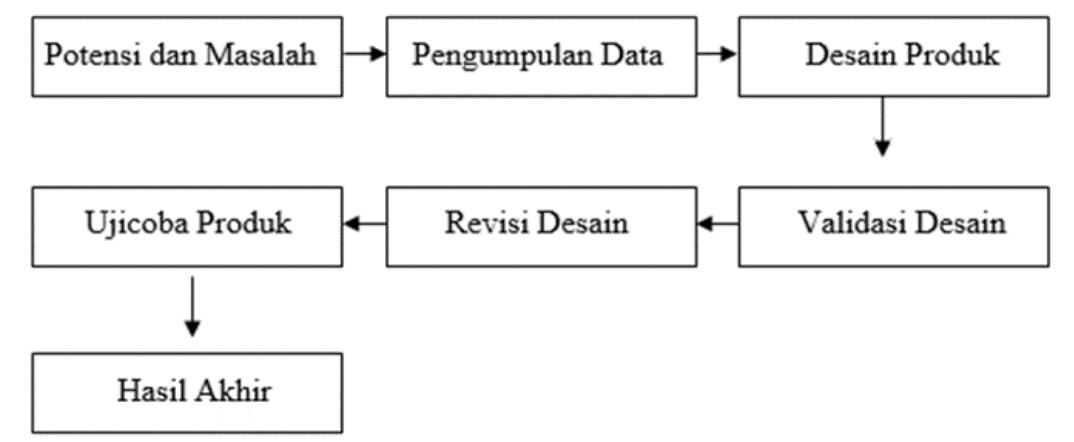

Berikut ini deskripsi dari masing-masing langkah-langkah yang disesuaikan dengan desain penelitian pengembangan video pembelajaran sebagai berikut: (1) Potensi dan masalah: dalam tahap ini dilakukan analisis potensi dan masalah dengan analisis kurikulum, analisis materi, dan analisis kebutuhan, analisis kebutuhan dengan cara observasi dan wawancara untuk 
mengetahui produk apa yang sesuai dengan karakteristik materi dan siswa; (2) Pengumpulan data: perlu dikumpulkan berbagai informasi dan data yang dapat digunakan sebagai bahan dalam pembuatan produk videoscribe; (3) Desain produk: dalam pembuatan videosribe ini mengacu pada SK/ KD/ Indikator; (4) Validasi desain: proses kegiatan untuk menilai apakah rancangan produk ini telah memenuhi kriteria kelayakan atau belum; (5) Revisi produk: produk selanjutnya direvisi/ diperbaiki berdasarkan saran dan masukan yang diberikan oleh para ahli; (6) Uji coba produk (uji coba terbatas): agar mengetahui respon serta penilaian peserta didik tentang videoscribe ini; Hasil akhir: produk video pembelajaran dengan berbasis aplikasi videoscribe pada mata pelajaran IPS dengan materi gejala alam untuk kelas VI SD.

Pengumpulan data yang dilakukan dalam peneltian ini dengan menggunakan (1) angket: bertujuan untuk mengetahui validasi kelayakan produk yang digunakan di dalam kelas dan mengetahui respon peserta didik terhadap produk pengembangan tersebut. Angket diberikan kepada ahli materi, ahli media, ahli pendidikan, dan peserta didik; dan (2) Dokumentasi: untuk memperkuat data yang diperoleh dari hasil angket.

Teknik analisis data dilakukan untuk mendapatkan media pembelajaran yang layak digunakan serta memenuhi kriteria kevaliditas. Penilaian dari hasil uji ahli dilakukan berdasarkan data menggunakan skala Likert dengan skor 1, 2, 3, 4, 5 .

Tabel B.1 Aturan Pemberian Skor Validasi Ahli

Sumber: Sugiyono, 2015:135

\begin{tabular}{clc}
\hline No & \multicolumn{1}{c}{ Kategori } & Skor \\
\hline 1 & Sangat Layak & 5 \\
\hline 2 & Layak & 4 \\
\hline 3 & Cukup Layak & 3 \\
\hline 4 & Kurang Layak & 2 \\
\hline 5 & Tidak Layak & 1 \\
\hline
\end{tabular}

Hasil yang sudah diperoleh dalam bentuk persen diubah kembali menjadi bentuk kualitatif sesuai dengan aturan yang telah diuraikan untuk menentukan kategori kelayakan video pembelajaran. Hasil uji oleh ahli dapat dinyatakan layak apabila memenuhi minimal kategori yaitu layak dengan persentase pada tabel B.2.

Tabel B.2 Interpretasi Kategori Kelayakan Video Pembelajaran

Sumber: Riduwan, 2009:41

\begin{tabular}{cc}
\hline Skor $(\%)$ & Kategori kelayakan \\
\hline $\mathrm{NP} \leq 20$ & Tidak layak \\
\hline $20<\mathrm{NP} \leq 40$ & Kurang layak \\
\hline $40<\mathrm{NP} \leq 60$ & Cukup layak \\
\hline $60<\mathrm{NP} \leq 80$ & Layak \\
\hline $80<\mathrm{NP} \leq 100$ & Sangat layak \\
\hline
\end{tabular}

Pada angket respon peserta didik terdiri dari pertanyaan positif dan negatif, angket tersebut berdasarkan daya menggunakan skala Likert dengan skor 1, 2, 3, 4 yang dapat dilihat pada tabel B.3

Tabel B.3 Aturan Pemberian Skor Respon Peserta Didik

Sumber: Riduwan, 2009:41

\begin{tabular}{cc}
\hline Skor $(\mathbf{\%})$ & Kategori kelayakan \\
\hline $\mathrm{NP} \leq 20$ & Tidak layak \\
\hline $20<\mathrm{NP} \leq 40$ & Kurang layak \\
\hline $40<\mathrm{NP} \leq 60$ & Cukup layak \\
\hline $60<\mathrm{NP} \leq 80$ & Layak \\
\hline $80<\mathrm{NP} \leq 100$ & Sangat layak \\
\hline
\end{tabular}

Vol. 11 No. 2 Juni 2019

Madrasah homepage: http://ejournal.uin-malang.ac.id/index.php/madrasah/index 


\section{MADRASAH}

Jurnal Pendidikan dan Pembelajaran Dasar

p ISSN: 1979-5599 | e ISSN: 2502-194X | Sinta 3

Pa g e | 5

Hasil uji coba terbatas terhadap video pembelajaran berbasis aplikasi videoscribe yang dilakukan oleh peserta didik dapat dinyatakan dengan baik apabila memenuhi minimal kategori yaitu baik dengan persentase pada tabel B.4.

Tabel B.4 Interpretasi Kategori Respon Peserta Didik

\begin{tabular}{cc}
\hline Skor (\%) & Kategori kelayakan \\
\hline $80<\mathrm{NP} \leq 100$ & Sangat Baik \\
\hline $60<\mathrm{NP} \leq 80$ & Baik \\
\hline $40<\mathrm{NP} \leq 60$ & Cukup \\
\hline $20<\mathrm{NP} \leq 40$ & Kurang \\
\hline $\mathrm{NP} \leq 20$ & Sangat Kurang \\
\hline
\end{tabular}

Sumber: Riduwan, 2009:41

\section{HASIL DAN PEMBAHASAN}

Hasil penelitian pada pengembangan video pembelajaran berbasis aplikasi videoscribe ini mengacu pada langkah-langkah yang telah dikembangkan oleh Sugiyono yaitu melakukan potensi dan masalah, pengumpulan data, desain produk, validasi desain, revisi desain, ujicoba produk.

1. Langkah-Langkah Pengembangan

a. Potensi dan Masalah

Tahap ini dilakukan analisis potensi dan masalah dengan (a) Analisis kurikulum: tahapan ini didapatkan hasil berupa analisis kurikulum yang mengacu pada Kurikulum Tingkat Satuan Pendidikan (KTSP) untuk kelas VI SD dengan mengidentifikasi standar kompentensi dan kompetensi dasar kemudian diuraikan menjadi indikator; (b) Analisis materi: Materi yang digunakan adalah materi gejala (peristiwa) alam yang terjadi di Indonesia yang terdapat pada Kurikulum Tingkat Satuan Pendidikan (KTSP). dan (c) Analisis kebutuhan: analisis kebutuhan pada materi gejala (peristiwa) alam yang terjadi di Indonesia di kelas VI SDN Panancangan 2 menunjukan bahwa media pembelajaran yang sering digunakan guru masih berupa gambar dan menggunakan aplikasi powerpoint sehingga media pembelajaran berupa video pembelajaran berbasis aplikasi videoscribe tidak ditemukan pada pembelajaran IPS.

b. Pengumpulan Data

Tahap ini mengumpulkan informasi mengenai perangkat pembelajaran dan referensi materi yang akan digunakan dalam media pembelajaran berupa video pembelajaran berbasis aplikasi videoscribe, mengumpulkan data yang diperlukan untuk video pembelajaran berbasis aplikasi videoscribe berupa gambar, animasi, dan suara yang digunakan sebagai bahan untuk produk yang akan dikembangkan. Setelah informasi dan data terpilih, kemudian melakukan penyesuaian dengan materi dan gambar yang akan dijadikan video pembelajaran.

c. Desain Produk

Pertama yang dilakukan dalam pembuatan produk ini yaitu dengan membuat storyboard. Storyboard bertujuan untuk mempermudah dalam pembuatan video pembelajaran dengan membuat konsep dan rancangan awal agar bagian-bagian dari video pembelajaran yang akan dibuat dapat tersusun dengan baik dan terstruktur. Pembuatan storyboard dengan mencantumkan tiap-tiap bagian dan deskripsi dari tiap bagian pada video pembelajaran. Selanjutnya, dilakukan pembuatan desain produk meliputi bagian pembuka, bagian isi/ materi, dan bagian penutup dari video pembelajaran. Bagian pembuka video berisikan gambar yang mendukung materi pembelajaran, dan tulisan yang mencantumkan judul dan mata pelajaran serta keterangan kelas pada materi di video pembelajaran tersebut, pada bagian pembuka video dibuat semenarik mungkin dan pada bagian pembuka video juga terdapat penjabaran SK/ KD/ Indikator serta tujuan pembelajaran dibuat untuk memberikan informasi materi pada video pembelajaran tersebut. Berikut adalah gambar tampilan video pembelajaran. 
Gambar C.1 Halaman Pembuka

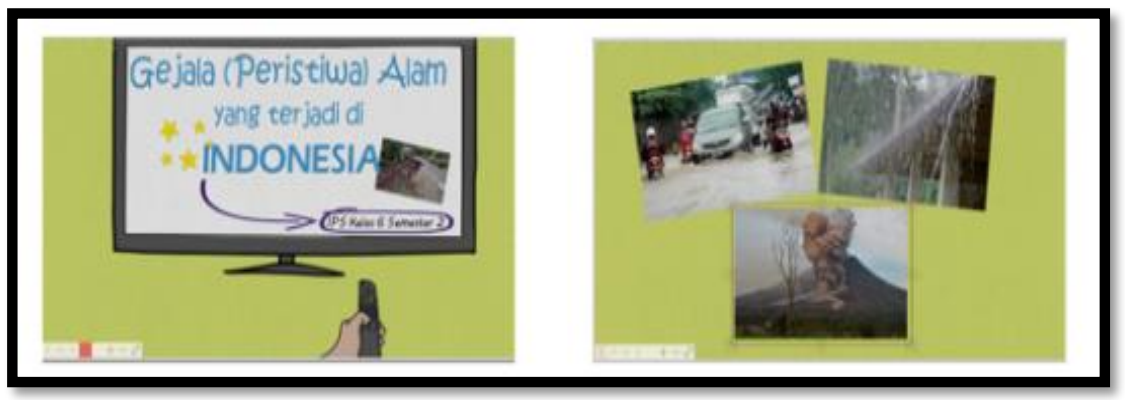

Bagian isi/ materi pada video pembelajaran sesuai pada Kompetensi Dasar 2.1 Mendeskripsikan gejala (peristiwa) alam yang terjadi di Indonesia. Bagian ini terdapat teks bacaan dan gambar pendukung yang berfungsi agar teks bacaan dari materi dapat lebih dipahami. Bagian isi/ materi dibuat interaktif agar terdapat interaksi dengan peserta didik.

Gambar C.2 Halaman Isi

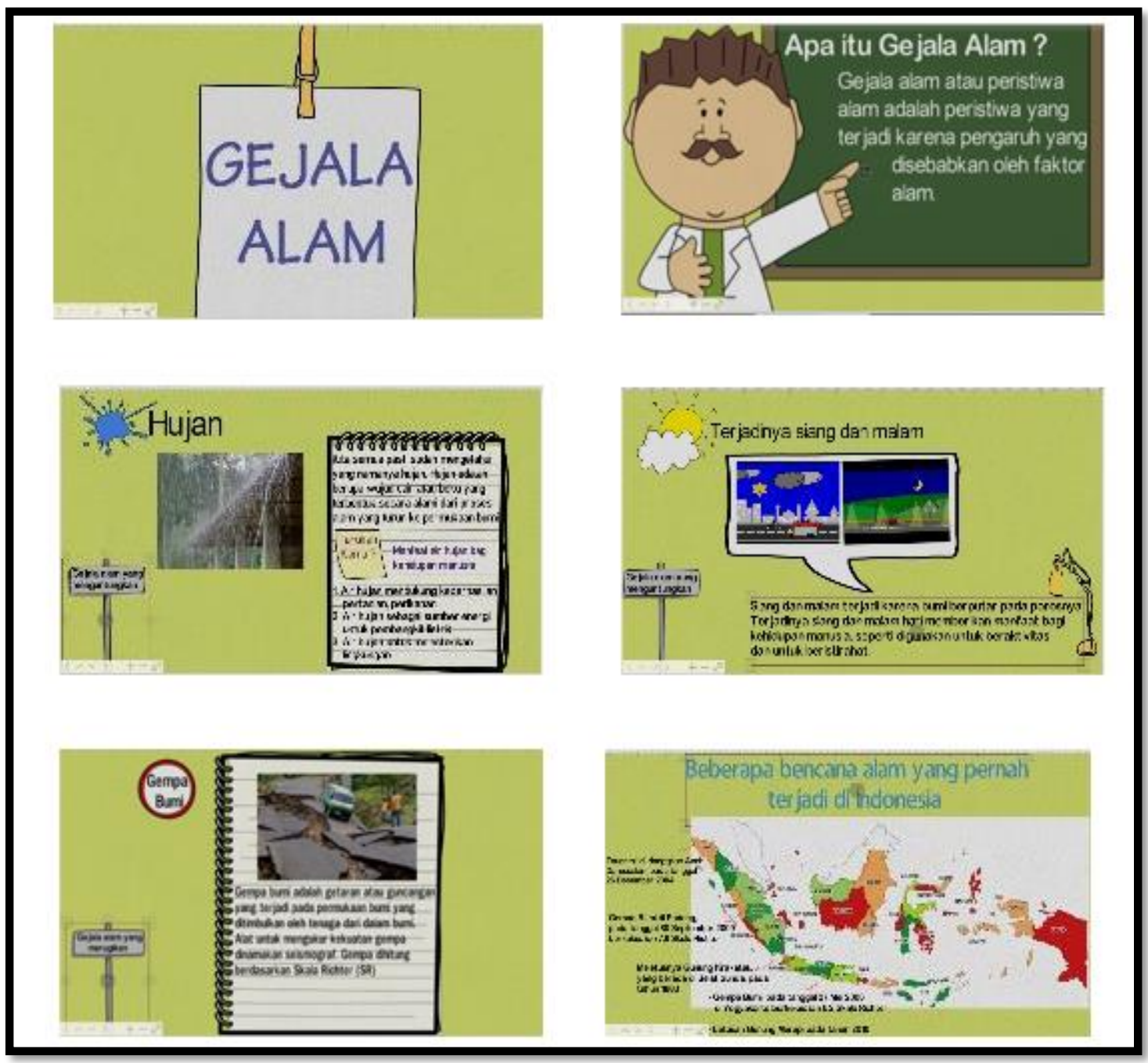

Pada bagian penutup terdapat kalimat penutup dan motivasi agar memberikan semangat kepada peserta didik serta bagian ini terdapat identitas pembuat video untuk memberikan informasi yang berisikan nama dan foto. 


\section{MADRASAH}

Jurnal Pendidikan dan Pembelajaran Dasar

p ISSN: $\underline{1979-5599}$ | e ISSN: 2502-194X | Sinta 3

Page $\mid 7$

Gambar C.3 Halaman Penutup

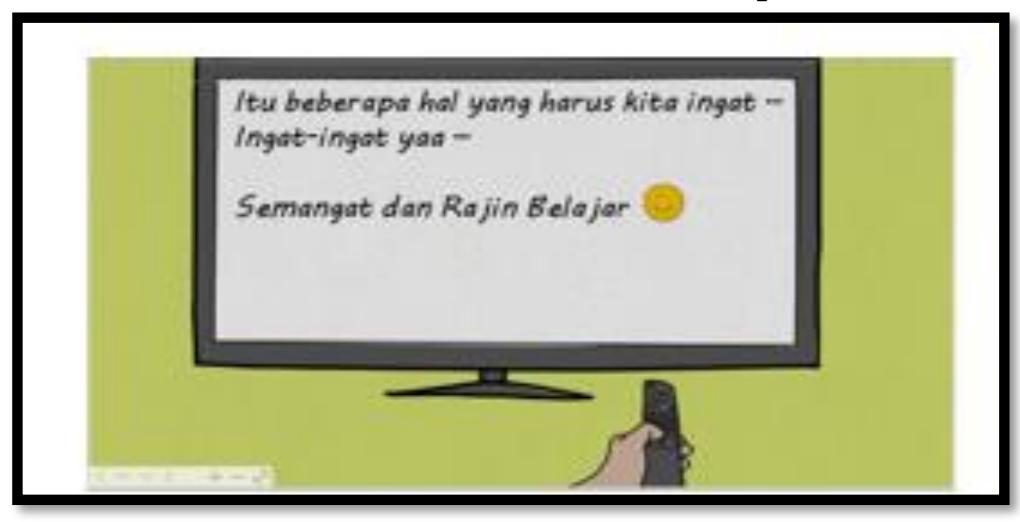

d. Validasi Desain;

Proses kegiatan untuk menilai apakah video pembelajaran berbasis aplikasi videoscribe yang dikembangkan telah memenuhi kriteria kelayakan atau belum. Produk berupa video pembelajaran ini dilakukan uji validasi oleh ahli materi, ahli media, dan ahli pendidikan.

1) Validasi Ahli Materi

Uji ahli materi ini dilakukan oleh Dosen Pendidikan Guru Sekolah Dasar FKIP Universitas Sultan Ageng Tirtayasa yaitu Zerri Rahman Hakim, M.Pd sebagai ahli materi I dan M. Taufik, M.Pd sebagai ahli materi II untuk memberikan saran serta penilaian terhadap video pembelajaran berbasis aplikasi videoscribe yang dikembangkan khususnya pada materi gejala alam sehingga dapat diketahui video pembelajaran yang dikembangkan sudah memenuhi kategori kelayakan atau belum.

Tabel C.1 Data Penilaian Uji Ahli Materi

\begin{tabular}{llccc}
\hline \multirow{2}{*}{ No } & \multirow{2}{*}{ Aspek } & \multicolumn{2}{c}{ Skor } & Rerata \\
& & Ahli I & Ahli II & Skor \\
\hline 1. & Tujuan pembelajaran & 13 & 12 & 12,5 \\
\hline 2. & Kesesuaian kompetensi dasar & 9 & 8 & 8,5 \\
\hline 3. & Kesesuaian tujuan pembelajaran dengan kompetensi dasar & 10 & 8 & 9 \\
\hline 4. & Kejelasan dan keakuratan materi & 13 & 11 & 12 \\
\hline 5. & Kemudahan materi untuk dipahami & 13 & 12 & 12,5 \\
\hline 6. & Kesesuian materi dengan tujuan pembelajaran & 14 & 12 & 13 \\
\hline 7. & Penguatan motivasi belajar & 8 & 6 & 7 \\
\hline 8. & Keteraturan pemakaian bahasa & 13 & 12 & 12,5 \\
\hline Nilai Rata-rata (\%) & 88,57 & 77,14 & 82,85 \\
\hline
\end{tabular}

Berdasarkan tabel diatas, uji validasi ahli materi diperoleh jumlah skor rata-rata 87 dengan skor maksimum sebesar 105 . Nilai rata-rata dengan persentase sebesar $82,85 \%$ masuk pada kategori "sangat layak".

2) Uji Validasi Ahli Media

Uji ahli media bertujuan untuk menilai media yang telah dikembangkan. Uji ahli ini dilakukan oleh A. Syachruroji, M.Pd (Dosen Pengampu Matakuliah Media Pembelajaran Jurusan Pendidikan Guru Sekolah Dasar FKIP UNTIRTA) sebagai ahli media I dan Eko Wahyu Wibowo, M.Si (Kepala Pusat Teknologi Informasi dan Pangkalan Data UIN SMH Banten) sebagai ahli media II . Untuk mengetahui penilaian serta masukan dari uji ahli ini terhadap video pembelajaran berbasis aplikasi videoscribe digunakan instrumen penilaian sebagai kritik dan saran agar video pembelajaran dapat diperbaiki. 
Tabel C.2 Data Penilaian Uji Ahli Media

\begin{tabular}{clccc}
\hline \multirow{2}{*}{ No } & \multirow{2}{*}{ Aspek } & \multicolumn{2}{c}{ Skor } & \multirow{2}{*}{ Rerata Skor } \\
\hline 1. & Kesederhanaan media & 13 & 14 & 13,5 \\
\hline 2. & Keterpaduan & 10 & 8 & 9 \\
\hline 3. & Keseimbangan & 14 & 13 & 13,5 \\
\hline 4. & Bentuk & 9 & 8 & 8,5 \\
\hline 5. & Warna & 9 & 8 & 8,5 \\
\hline Nilai Rata-rata (\%) & 91,67 & 85 & 88,34 \\
\hline
\end{tabular}

Pada tabel diatas, penilaian uji validasi ahli media diperoleh jumlah skor rata-rata 53 dengan skor maksimum sebesar 60 . Nilai rata-rata dengan persentase sebesar $88,34 \%$ masuk pada kategori "sangat layak".

\section{3) Uji Ahli Pendidikan}

Uji ahli ini dilakukan oleh Guru kelas VI SDN Panancangan 2 yaitu Septi Kusrini, S.Pd sebagai ahli pendidikan I dan Rahmah Utaminarsih, S.Pd sebagai ahli pendidikan II yang diharapkan dapat memberikan penilaian dan saran untuk videoscribe yang dikembangkan ini.

Tabel C.3 Data Penilaian Uji Ahli Pendidikan

\begin{tabular}{clccc}
\hline \multirow{2}{*}{ No } & \multirow{2}{*}{ Aspek } & \multicolumn{2}{c}{ Skor } & \multirow{2}{*}{ Rerata Skor } \\
\cline { 3 - 4 } & & Ahli I & Ahli II & \\
\hline 1. & Tujuan pembelajaran & 5 & 5 & 5 \\
\hline 2. & Aktivitas peserta didik & 17 & 17 & 17 \\
\hline 3. & Penyajian & 8 & 8 & 8 \\
\hline 4. & Tampilan & 14 & 12 & 13 \\
\hline 5. & Pengaplikasian & 8 & 9 & 8,5 \\
\hline & Nilai Rata-rata (\%) & 86,67 & 85 & 85,83 \\
\hline
\end{tabular}

Pada tabel diatas, uji validasi ahli pendidikan diperoleh jumlah skor rata-rata 51,5 dengan skor maksimum sebesar 60 . Nilai rata-rata dengan persentase sebesar 85,83 masuk pada kategori "sangat layak".

e. Revisi Desain

Setelah produk divalidasi oleh para ahli, maka dapat diketahui saran dan masukan. Produk tersebut selanjutnya direvisi/diperbaiki berdasarkan saran dan masukan yang diberikan oleh 3 ahli yaitu ahli materi, ahli media, dan ahli pendidikan.

f. Uji coba produk (Uji coba terbatas);

Video pembelajaran berbasis aplikasi videoscribe yang telah divalidasi dan dilakukannya revisi berdasarkan saran dan penilaian dari para ahli selanjutnya dilakukan uji coba produk (uji coba terbatas). Uji coba produk ini bertujuan untuk mengetahui respon serta penilaian peserta didik terhadap video pembelajaran berbasis aplikasi videoscribe. Untuk mengetahui respon dari peserta didik, video pembelajaran berbasis aplikasi videoscribe ini dilakukan uji coba terbatas kepada peserta didik kelas VI A SDN Panancangan 2, Kec. Cipocok Jaya, Kota Serang dengan jumlah peserta didik sebanyak 43 orang sebagai responden. Berikut analisis data hasil respon peserta didik terhadap video pembelajaran berbasis aplikasi videoscribe:

Tabel C.4 Data Hasil Respon Peserta Didik

\begin{tabular}{cccc}
\hline No. & Aspek & Skor & Nilai Akhir (\%) \\
\hline 1. & Isi/ Materi & 474 & 91,86 \\
\hline 2. & Bahasa & 157 & 91,27 \\
\hline 3. & Ketertarikan & 456 & 88,37 \\
\hline 4. & Kegrafikan & 468 & 90,69 \\
\hline & Total Skor & $\mathbf{1 5 5 9}$ & $\mathbf{9 0 , 5 2}$ \\
\hline
\end{tabular}




\section{MADRASAH}

Jurnal Pendidikan dan Pembelajaran Dasar

p ISSN: $\underline{1979-5599}$ | e ISSN: 2502-194X | Sinta 3

Pag e | 9

Berdasarkan tabel diatas, hasil respon peserta didik terhadap video pembelajaran berbasis aplikasi videoscribe diperoleh persentase nilai akhir sebesar 90,52\% masuk dalam kategori "sangat baik".

g. Hasil Akhir

Setelah dilakukannya beberapa tahap yaitu potensi dan masalah, pengumpulan data, desain produk, uji validasi ahli, revisi produk, ujicoba produk maka akan menghasilkan produk berupa video pembelajaran berbasis aplikasi videoscribe pada mata pelajaran IPS dengan materi gejala alam untuk kelas VI SD. Produk ini dikemas dalam bentuk softcopy dan dimasukkan ke dalam CD/ DVD.

Pengembangan video pembelajaran ini mengacu pada langkah-langkah yang dikembangkan oleh Sugiyono, yaitu potensi dan masalah, pengumpulan data, desain produk, uji validasi ahli, revisi produk, ujicoba produk (ujicoba terbatas), dan hasil akhir.

Pada tahap potensi masalah dilakukan beberapa analisis yaitu analisis kurikulum, analisis materi, dan analisis kebutuhan. Pada tahap pengumpulan data dilakukan pengumpulan berbagai informasi dan data yang dapat digunakan sebagai bahan dalam pembuatan produk videoscribe seperti perangkat pembelajaran, referensi materi, gambar, dan suara yang akan digunakan dalam video pembelajaran. Selanjutnya dilakukan tahap desain produk. Diawali dengan pembuatan storyboard/ rancangan produk. Tahap pembuatan desain produk meliputi bagian pembuka, bagian isi/ materi, dan bagian penutup dari video pembelajaran.

Tahap selanjutnya yaitu uji validasi ahli.Terdapat 3 uji validasi ahli yang dilakukan yaitu validasi ahli materi, ahli media, dan ahli pendidikan. Didapatkan perolehan persentase nilai ratarata uji ahli materi sebesar $82,85 \%$ dengan kategori sangat layak. Selanjutnya uji ahli media diperoleh persentase nilai rata-rata sebesar $88,34 \%$ dengan kategori sangat layak. Kemudian hasil penilaian dari uji ahli pendidikan diperoleh persentase nilai rata-rata sebesar $85,84 \%$ dengan kategori sangat layak. Dari hasil penilaian uji validasi ahli, video pembelajaran berbasis aplikasi videoscribe memperoleh persentase rata-rata nilai sebesar $85,67 \%$ dan dinyatakan dengan kategori sangat layak. Berikut hasil penilaian uji validasi ahli dalam bentuk tabel:

Tabel C.5 Hasil Penilaian Uji Validasi Ahli

\begin{tabular}{ccc}
\hline Validasi Ahli & Nilai Rerata (\%) & Kategori \\
\hline Ahli Materi & 82,85 & Sangat Layak \\
\hline Ahli Media & 88,34 & Sangat Layak \\
\hline Ahli Pendidikan & 85,84 & Sangat Layak \\
\hline Rata-Rata & $\mathbf{8 5 , 6 7}$ & Sangat Layak \\
\hline
\end{tabular}

Setelah melakukan uji validasi ahli dan revisi maka produk dapat diuji coba terbatas pada SD kelas VI. Uji coba terbatas dilakukan di kelas VI A SD Negeri Panancangan 2 dengan peserta didik berjumlah 43 orang. Uji coba ini dilakukan dengan menampilkan video pembelajaran berbasis aplikasi videoscribe menggunakan LCD proyektor didepan kelas.

Terdapat 4 aspek pada angket respon peserta didik terhadap video pembelajaran berbasis videoscribe yaitu: isi/materi, bahasa, ketertarikan, dan kegrafikan. Hasil uji coba terbatas terhadap video pembelajaran berbasis videoscribe diperoleh persentase nilai akhir sebesar 90,52\% masuk dalam kategori "sangat baik". Hal ini menunjukan bahwa semua aspek dapat terpenuhi dengan baik. Peserta didik menyatakan isi/ materi yang disajikan dalam media pembelajaran berupa video pembelajaran berbasis videoscribe mudah dipahami. Hasil penilaian respon peserta didik pada aspek isi/ materi memperoleh persentasi nilai sebesar $91,86 \%$ dengan kategori sangat baik. Hal ini sesuai dengan pernyataan Sudjana dan Rivai (2010:2) yang menyatakan bahwa media pembelajaran dapat memberikan bahan (materi) pengajaran menjadi

Vol. 11 No. 2 Juni 2019

Madrasah homepage: http://ejournal.uin-malang.ac.id/index.php/madrasah/index 
lebih jelas maknanya sehingga dapat lebih dipahami oleh peserta didik dan memungkinkannya menguasai dan mencapai tujuan pembelajaran.

Pada aspek bahasa memperoleh persentase nilai sebesar 91,27\% dengan kategori sangat baik. Peserta didik menyatakan bahwa video pembelajaran berbasis videosribe menggunakan bahasa yang sederhana dan mudah dimengerti karena penggunaan bahasa sesuai EYD. Hal ini sesuai dengan pernyataan Partin (2009:171) menyatakan bahwa media audio-visual dapat membawa peserta didik ke tempat-tempat yang tak kan pernah mereka kunjungi, membantu mereka melihat hal-hal yang mungkin tak pernah mereka alami, dan menjadikan hal-hal yang mereka baca menjadi hidup.

Sedangkan aspek ketertarikan memperoleh persentase nilai sebesar 88,37\% dengan kategori sangat baik. Peserta didik menyatakan senang setelah menonton video pembelajaran berbasis aplikasi videoscribe dan menjadi lebih tahu tentang materi yang terdapat dalam video serta ingin lebih mengetahui akan pelajaran IPS. Hal ini sesuai dengan pernyataan Sudjana dan Rivai (2010:2) yang menyatakan bahwa media pembelajaran akan membuat pengajaran akan lebih menarik perhatian peserta didik sehingga dapat menumbuhkan motivasi belajar.

Pada aspek kegrafikan memperoleh persentase nilai sebesar 90,69\% dengan kategori sangat baik. Peserta didik menyatakan gambar yang digunakan sangat menarik sehingga dapat mudah memahami materi dari video yang disajikan. Hal ini sesuai dengan pernyataan Daryanto (2010:88) yang menyatakan bahwa dengan adanya simbol seperti kata-kata, kalimat disertai gambar dan audiovisual, maka videoscribe dapat membantu peserta didik dengan mudah memahami apa yang hendak dipesankan oleh guru yaitu berupa materi pembelajaran.

Pada saat penggunaan video pembelajaran berbasis aplikasi videoscribe, peserta didik memperhatikan video dengan baik karena memiliki ketertarikan dengan materi yang disajikan dalam video pembelajaran dengan gambar, suara, tampilan yang menarik serta materi dan bahasa sederhana sehingga materi yang terdapat pada video pembelajaran berbasis aplikasi videoscribe mudah dimengerti oleh peserta didik. Hal ini sesuai dengan penelitian Minarni yang berjudul Pemanfaatan Media Pembelajaran Ilmu Pengetahuan Alam (IPA) Berbasis Video Menggunakan Aplikasi Video Scribe Untuk Anak Kelas 2 Sekolah Dasar, menunjukkan bahwa videoscribe dapat dimanfaatkan sebagai media pembelajaran anak Sekolah Dasar untuk membantu guru dalam menyampaikan materi yang dipandang perlu hal-hal menarik dalam penyampaian agar peserta didik dapat mudah mengingat dan memahami.

Joyce dan B. White (Wulandari, 2016) yang berjudul Pengembangan Media Pembelajaran Menggunakan Sparkol Videoscribe dalam Meningkatkan Minat Belajar Siswa pada Mata Pelajaran IPA Materi Cahaya Kelas VIII di SMP Negeri 01 Kerjo Tahun Ajaran 2015/2016 juga menyatakan dimana sparkol videoscribe dapat meningkatkan antusiasme peserta didik dalam mengikuti pembelajaran karena media pembelajaran ini mampu memberikan pengalaman belajar yang menyenangkan dan efisisen.

Berdasarkan pembahasan tersebut menunjukkan bahwa video pembelajaran berbasis aplikasi videoscribe untuk mata pelajaran IPS materi gejala (peristiwa) alam yang terjadi di Indonesia termasuk dalam kategori sangat layak menurut ahli materi, ahli media, dan ahli pendidikan dan memperoleh kategori sangat baik saat dilakukan uji coba terbatas kepada peserta didik.

\section{KESIMPULAN}

Berdasarkan hasil penelitian dan pembahasan pada pengembangan video pembelajaran berbasis aplikasi videoscribe dengan materi gejala (peristiwa) alam yang terjadi di Indonesia pada mata pelajaran IPS kelas VI SD, maka dapat diambil simpulan bahwa hasil uji validasi ahli dinyatakan kategori sangat layak. 


\section{MADRASAH}

Jurnal Pendidikan dan Pembelajaran Dasar

p ISSN: 1979-5599 | e ISSN: 2502-194X | Sinta 3

Page | 11

\section{REFERENSI}

Annetta, L. A., Minogue, J., Holmes, S. Y., \& Cheng, M. T. (2009). Investigating the impact of video games on high school students' engagement and learning about genetics. Computers \& Education, 53(1), 74-85.

Daryanto. 2010. Media Pembelajaran: Peranannya Sangat Penting dalam Mencapai Tujuan Pembelajaran. Yogyakarta: Gaya Media.

Minarni, M. (2016). Pemanfaatan Media Pembelajaran Ilmu Pengetahuan Alam (Ipa) Berbasis Video Menggunakan Aplikasi Video Scribe Untuk Anak Kelas 2 Sekolah Dasar. Jurnal Penelitian Dosen FIKOM (UNDA), 5(1).

Partin, Robert L. 2009. Kiat Nyaman Mengajar Di Dalam Kelas. Jakarta: Indeks.

Purnama, dkk. 2017. Pengembangan Media Video Animasi Berbasis Videoscribe Pada Materi Koloid Untuk Mahasiswa Program Studi Pendidikan Fisika Tahun Akdemik 2016-2017. Jurnal Ilmiah Mahasiswa Pendidikan Kimia (JIMPK) Vol. 2 No. 3, hal 253-260.

Riduwan. 2009. Dasar-Dasar Statistika. Bandung: Alfabeta.

Sadiman, Arief, dkk. 2010. Media Pendidikan; Pengertian, Pengembangan, dan Pemanfaatannya. Jakarta: Raja Grafindo Persada

Sudjana, Nana dan Rivai, Ahmad. 2010. Media Pengajaran. Bandung: Sinar Baru Algensindo Offset.

Sugiyono. 2015. Metode Penelitian Pendidikan; Pendekatan Kuantitatif, Kualitatif, dan R\&D). Bandung: Alfabeta

Wulandari, Dyah Ayu. 2016. Pengembangan Media Pembelajaran Menggunakan Sparkol Videoscribe Dalam Meningkatkan Minat Belajar Siswa Pada Mata Pelajaran IPA Materi Cahaya Kelas VIII di SMP Negeri 01 Kerjo Tahun Ajaran 2015 / 2016. Skripsi. Semarang: Universitas Negeri Semarang.

Zhang, D., Zhou, L., Briggs, R. O., \& Nunamaker Jr, J. F. (2006). Instructional video in elearning: Assessing the impact of interactive video on learning effectiveness. Information \& management, 43(1), 15-27. 